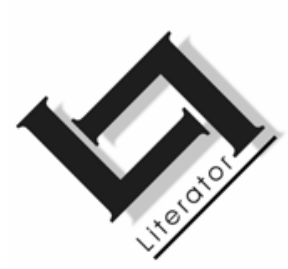

\title{
Breyten Breytenbach se Boek. die taal (poësie) as voelinstrument om bewussyn te verken
}

\author{
Willie Burger \\ Departement Afrikaans \\ Universiteit van Johannesburg \\ JOHANNESBURG \\ E-pos:wdb@rau.ac.za
}

\section{Abstract \\ Breyten Breytenbach's Boek: language (poetry) as feeling- instrument to explore consciousness}

One of the big questions of science is the mystery of consciousness. How is it possible that a state of consciousness, an awareness of your own being and actions, can originate from matter, from the movement of neurons in nerve tissue? While neuroscience does not have answers to these questions (yet), the subjective exploration of consciousness by means of works of art, could make a valuable contribution. Breyten Breytenbach explicitly views his art (writing and painting) as ways to investigate consciousness.

In "Boek" (1987) Breytenbach explains his views on art. In this complex work, he focusses, among other aspects, on the idea that the work of art, at a specific moment, produces an "other", a meaning that has not hitherto existed somewhere, waiting to be discovered. This hitherto unknown meaning comes into existence in the moment of creation.

The creative moment in which the hitherto unknown is wrestled from the known, cannot be produced by following a recipe. The unknown, the other, virtually invades the world of the artist, as if the work of art happens to the artist, instead of him creating it. This experience has a changing effect on the artist and in the process he learns more about his own consciousness.

The changing effect is not restricted to the artist, as the reader of the poem shares this experience. Because the reader is also 
writer, according to Breytenbach, the work of art is recreated by the reader and the reader has the same experience of a virtual invasion of the "other" on his/her own life and in the process also discovers more about his/her own consciousness.

\section{Opsomming}

\section{Breyten Breytenbach se Boek. die taal (poësie) as voel- instrument om bewussyn te verken}

Een van die groot vraagstukke in die natuurwetenskap is die misterie van bewussyn. Hoe is dit moontlik dat 'n staat van bewussyn, 'n besef van jou eie bestaan en jou handelinge kan ontstaan uit materie, uit neuronbewegings in 'n stuk senuweefsel? Terwyl die neurowetenskap (nog) nie antwoorde hierop het nie, kan die subjektiewe ondersoek van bewussyn in kunswerke ook aandag ontvang. Breyten Breytenbach beskou sy kuns, beeldend sowel as poësie, as 'n manier om bewussyn te ondersoek.

In "Boek" (1987) sit Breytenbach sy kunsbeskouing uiteen. Een van die verskeie fasette wat hy in hierdie komplekse werk aanroer, is dat daar in die kunswerk, op 'n sekere moment, 'n "ander betekenis" tot stand kom wat nie vooraf reeds iewers bestaan en wag op ontdekking nie. Hierdie betekenis kom tot stand in die moment waarop die bekende vervorm word.

Hierdie kreatiewe moment waarop die tot-dusver-onbekende uit die bekende losgeworstel word, kan egter nie op 'n resepmatige wyse voorgebring word nie. Hierdie onbekende, die ander, maak as't ware uit 'n ander wêreld inbreuk op die kunstenaar se wêreld - asof die ontstaan van die kunswerk mét hom gebeur eerder as wat hy dit láát gebeur. Dit is 'n veranderende ervaring, waardeur die kunstenaar iets meer van sy eie bewussyn leer ken.

Die veranderende ervaring is egter nie slegs die kunstenaar s'n nie. Dit geld ook vir die waarnemer van die kunswerk. Omdat die leser ook skrywer is, omdat die kunswerk telkens deur die waarnemer daarvan op 'n manier "herskep" word, het ook die waarnemer hierdie ervaring van 'n ingryp van elders op sy lewe en die lees van poësie is dus ook 'n verkenning van die eie bewussyn.

\section{Inleiding: bewussyn en die kuns}

Een van die groot vraagstukke in die natuurwetenskap is die misterie van bewussyn. Hoe is dit moontlik dat 'n staat van bewussyn, 'n besef van jou eie bestaan en jou handelinge kan 
ontstaan uit materie, uit neuronbewegings in 'n stuk senuweefsel?1 Soos Peter Lipton (1998:217) dit stel:

... conscious states seem to have features that no purely physical system could possess, and (because) any connection between physical and conscious states appears to be contingent.

Die neurowetenskap kan deur talle tegnologiese ontwikkelings aandui waar aktiwiteit in die brein plaasvind; dit kan die aard van die aktiwiteit beskryf en byvoorbeeld verduidelik hoe die brein kleure onderskei of handelinge organiseer, maar die groot probleem bly: hoe kan objektief waarneembare dinge soos breinselle, weefsel, neurone en bloed aanleiding gee tot die hoogs subjektiewe ervaring dat daar 'n "ek" is wat kan ruik en proe, wat 'n nooi in 'n nartjie of 'n ouma in kaneel kan hê? (Hierdie probleem, naamlik om die bestaan van die sogenaamde qualia te verklaar, staan sentraal in verskeie ondersoeke na die bewussyn. ${ }^{2}$ )

William James (1890) het 'n "bewussynstroom" as vertrekpunt vir sy sielkunde geneem. Die bewussynstroom is daardie konstante, maar voortdurend veranderende vloei van idees, waarnemings, gevoelens en emosies wat elkeen van ons ervaar. Die vraag na hierdie stroom is steeds onopgeklaar deur die wetenskap, soos ook die vraag na wie die "ek" is wat hierdie bewussynstroom ervaar. Trouens, volgens talle eksperimentele navorsingsprojekte wil dit lyk asof daar nie eens so 'n bewussynstroom bestaan nie.

Terwyl neuroloë, deur steeds fyner meetinstrumente en eksperimentering, op baie maniere probeer om 'n objektiewe, wetenskaplike basis te vind vir bewussyn, is dit steeds moeilik om verbande te lê tussen subjektiewe ervarings en breinprosesse. Baie neuroloë redeneer dat die neurowetenskap uiteindelik sodanig sal vorder dat die misterie van bewussyn volledig verklaar sal kan word (o.a. Penrose, 1994 en Crick, 1994). Op die oomblik is talle korrelasies tussen objektief-waarneembare breinaktiwiteit en subjektiewe ervarings wel aantoonbaar, maar hierdie korrelasies is nog nie werklik 'n verduideliking van bewussyn nie. Ook is 'n groterwordende hoeveelheid van hierdie korrelasies nie genoeg om bewussyn te verklaar nie:

$1 \quad$ Vir besprekings hiervan, kyk byvoorbeeld na Dennett (1991), Searle (1992; 1998) en Boden (1998).

2 Vir besprekings van qualia en bewussyn, kyk onder andere na Boden (1998:1-3). 
This is not to deny that some future science might explain it. But this could not be done merely by adding new details, or even new categories, to our current neuroscience. An adequate explanation of the cerebral basis (and the evolutionary origin) of consciousness would involve such a radical shift in our contemporary scientific and philosophical assumptions that we can have no idea, at present, what such an explanation might be like. In this sense, then, I agree with Fodor that we have not the slightest idea how anything material could be conscious (Boden, 1998:10).

Terwyl neurowetenskaplike navorsing steeds nie die misterie van bewussyn bevredigend kon oplos nie, is dit dalk sinvol om kunswerke as 'n metode waarop meer van die bewussyn verstaan kan word, te ondersoek. Die skeppende proses, die maak van poësie, is een manier waarop die kunstenaar (die digter) sy/haar bewussyn kan verken. Breyten Breytenbach beskou sy kuns, beeldend sowel as poësie, as 'n manier om bewussyn te ondersoek. In 'n onderhoud spreek Breytenbach (1997) hom soos volg uit:

If I were to draw out one thing, for myself, about everything that I tried to do in writing and painting over the years it would be about the nature of consciousness. That's actually what it's about: the nature of consciousness and what you can do with it, in other words, what is it to experience something? What is it to know something? What is it to see? What is it to be able to say something, and what is it that you do with it then? How do you transform it then ... and within that given or calculation, the observation point, the observation person is obviously very important.

To me there is no contrast, lets say, in the Buddhist view of Not One, there is no isolatable, unchangeable ego or soul or ' 1 ' with which you would be able to work from beginning to end. To me there is no contest between that and the fact that you always work from the very personal point of view. Because I think it is a mechanism. The ' $l$ ' is a mechanism. The ' $l$ ' figure in the poem is a mechanism. But naturally it always refers to experience, provided that that experience can also be imagination.

Hierdie sentrale tema in Breytenbach se werk, wat hy koppel aan sowel sy skryfwerk as sy skilderwerk, naamlik die ondersoek van bewussyn, die aard van bewussyn, die aard van ervaring en waarneming en die neerslag van hierdie ervarings en waarnemings in die skeppende werk, word in Boek (1987) ondersoek. In hierdie werk sit Breytenbach sy poësiebeskouing en dus ook sy kunsbeskouing uiteen. 


\section{Boek}

Boek het in 1987 by Taurus verskyn. Dit is geskryf in die tyd toe Breytenbach tronkstraf uitgedien het (1975-1982). Hy het die boek in moeilike omstandighede geskryf. Hoewel hy toegelaat is om in die tronk te skryf, is alles wat hy geskryf het aan die einde van elke dag uit sy sel verwyder. Hy het dus nie die geleentheid gehad om te herlees, te redigeer en seker te maak dat hy aansluit by die plek waar hy die vorige dag opgehou het nie. Dit maak van hierdie boek 'n taamlik moeilike leeservaring.

Die boek is 'n nadink oor die kreatiewe proses, maar dit word ook 'n demonstrasie van die skeppingsproses (veral in die voorlaaste afdeling, 1.15). Op hierdie manier word iets blootgelê van die manier waarop die poësie 'n verkenning van die bewussyn is. Hierdie blootlegging geld nie alleen die verkenning van die kunstenaar, dus die digter se bewussyn deur die gedig nie, maar ook van die leser van die gedig.

Breytenbach skryf voorin Boek, hierdie is "Voetnote by Om te Vlieg". Breyten beskryf die ervaring van "inspirasie", van die kreatiewe proses, aan die hand van hoe hy Om te vlieg 3 as't ware eensklaps, in geheel "ontvang" het en kon neerskryf: "Ek het so ervaring gehad met die konsepsie van Om te vlieg jare gelede" p. 6.4 Hy verwys verder ook na die ontstaansproses en werkswyse wat hy volg in die digbundels (die ongedanste dans) en die prosawerk Mouroir, waaraan hy werk terwyl hy Boek skryf:

Ek is tans besig met die afwerk van 'n bundel wat ek Buffalo Bill wil noem. Terselfdertyd werk ek aan 'n prosakonstruksie wat voorlopig Mouroir heet (p. 187)

Hierdie nadenke oor die kreatiewe proses, oor kuns, oor die poësie, word dus gedoen vanuit 'n posisie in die midde van die kreatiewe proses. Breytenbach stel ook nie die ander werk hoër as hierdie nie:

3 Om te vlieg: 'n Opstel in vyf ledemate en 'n ode is waarskynlik geskryf in Parys tussen 1963 en 1965 en is in 1971 gepubliseer. 'n Verteller-karakter, Panus, in Slagterstad het 'n groot begeerte om te vlieg (wat saamhang met die begeerte om te skryf).

4 Die ervaring dat die kunswerk "ontvang" word, word later in hierdie opstel verder ondersoek, maar dit is opvallend dat ook Karel Schoeman voortdurend daarop wys dat boeke vir hom "gegee" word. Dit sluit ook aan by Derrida se idee van gasvryheid (2000), dat iets aan 'n mens gebied word.

5 Bladsynommers tussen hakies, sonder aanduiding van outeur of datum, verwys na Breytenbach (1987). 
Moet asseblief nie verwag dat my logboek, my besinning oor my werk, insiggewend moet wees nie, nie meer so as die gedigte nie (en hopelik ook nie minder nie); dit dek dieselfde veld as die verse (my kursivering - WDB) (p. 89).

Die veld wat hier ter sprake is, het juis te doen met die skeppende moment. Gevolglik is dit ook nie vreemd dat hy die boek 'n "joernaal" noem nie en die losse strukturering spruit uit die feit dat dit as "proses" aangebied word - waardeur iets van die kreatiewe proses ook gedemonstreer word.

Hoewel Breytenbach aanvanklik nog probeer om 'n struktuur aan die joernaal te gee (en die numering van die afdelings is hiervan teken en parodie), verduidelik hy later dat hy selfs die vae struktuur wat hy aanvanklik wou gebruik, "nou laat regs lê" (p. 82-83). Die rede daarvoor gee hy ook - dit is juis in die skryfproses waarin hy ontdek hoe die skryfproses werk, waarin hy ontdek wat hy wil sê:

Ek bevestig dit weer - ek skryf agter die skrywe aan - ek skryf agter die woorde aan - en sien wat kom; en sien kom klaar (p. 83). 6

Die implikasie hiervan is egter nie dat Boek ongestruktureer is nie. Soos die vrye vers wat hy beoefen (en waaroor hy ook skryf, p. 106) sekere bindmiddels het wat verskil van die tradisionele, is daar ook in hierdie boek sekere bindmiddels. Hierdie boek kan egter nie "wetenskap" wees volgens die natuurwetenskapsmodel nie. Breytenbach verwerp immers die logika "as gangbare manier om die poësie te betrap en onder taal te bring" (p. 134). ${ }^{7}$ Logika is maar "dinktrekkings" (n.a.v. dronktrekkings). Logika is verstrengel in die wetenskaplike denke (aanleiding daartoe en produk daarvan) en

6 Hierdie idee word ook in die werk van J.M. Coetzee aangetref. Coetzee skryf in Doubling the point (1992:18):

It is naïve to think that writing is a simple two-stage process: first you decide what you want to say, then you say it. On the contrary, as all of us know, you write because you do not know what you want to say. Writing reveals to you what you wanted to say in the first place. In fact, it sometimes constructs what you want to or wanted to say. What it reveals (or asserts) may be quite different from what you thought (or half-thought) you wanted to say in the first place. That is the sense in which one can say that writing writes us. Writing shows or creates (and we are not always sure we can tell the one from the other) what our desire was, a moment ago.

7 Attridge wyt die ondefinieerbaarheid van letterkunde daaraan dat dit nooit vasgepen kan word nie. Hy skryf: (2004:138), "My attempt to convey in the language of argument and description the essence of the literary has, of course, failed; but as an event communicated in the event of reading, this failure offer itself as testimony to the persistence and vitality of literature." 
"prosedeer dus by weë van isolering en verbrokkeling, kan die totaliteit nie by die horings gryp nie" (p. 134).

Breytenbach verwerp egter die logika as bloot 'n manier om die "poësie te betrap" en nie as sodanig nie. Hy beskou die logika as 'n "nuttige denktrekking", solank onthou word dat die rede "'n dissipline van die verbeelding is" (p. 135).

Ek het hierbo verwys na die feit dat Breytenbach Boek in die tronk geskryf het - dieselfde tyd wat hy gewerk het aan bundels soos Buffalo Bill en Mouroir. Die opmerking is nie net 'n kuriositeit nie, maar dit is belangrik dat hierby ook onthou moet word dat hy as gevolg van hierdie omstandighede nie bronne vrylik tot sy beskikking gehad het nie. Die bronne waarna hy verwys kan sekerlik 'n eie studie regverdig, maar dit is duidelik dat hy nie sistematiese toegang tot enige bronne gehad het nie, soos hy self ook aan die begin skryf:

Ek het aangekondig dat ek wil uitlê hoe 'n gedig ontstaan en ek weet reeds dat ek verdwaal gaan raak in die labirint van wát die gedig is. Erger nog; ek gaan didakties word en daartoe verlei word om te probeer vertel wat 'n gedig behoort te wees en nie wat dit is nie. En as ek in daardie pogings van my maar kon steun op die refleksies van Majakofski, van Lorca, van Van Ostaijen en Joris Ivens, van Adorno en Gramsci, van Brecht of Benjamin of Althusser - maar hulle is afwesig! (p. 10).

Die subtitel van Boek lui: "Dryfpunt; of oor die ontstaan van 'n gedig". Die term dryfpunt is tipies van Breyten se woordkeuse - dit is veelduidig. Hy wil 'n punt maak, die punt sterk stel en so ver dryf as wat hy kan. Ook die idee van dryf op water, van ronddobber, is egter hierin te bespeur - dat die punt wat hy probeer maak, nie vaspenbaar is nie, maar ronddobber, ronddryf; selfs dat hy gedurig van die punt (die maak van 'n gedig) gaan wegdryf. Later speel hy ook in op die betekenis van "afdryf", "puntafdrywing" (die idee van vrugafdrywing) met die suggestie dat hierdie boek 'n abortiewe poging is om die gedig se ontstaan vas te pen.

In die woord dryfpunt is dus tot 'n sekere mate reeds veel vasgevang van die punt wat Breytenbach oor die kunswerk maak. Die term dryfpunt is 'n kreatiewe vonds wat spruit uit die benutting van die bekende in 'n nuwe kombinasie, wat lei tot die ontdekking van ander, tot dusver onbekende moontlikhede. Die ontdekking van die "ander", van die onbekende, deur gebruik te maak van die bekende, is vir Breytenbach kenmerkend van die ontstaan van die kunswerk. 


\section{Die kreatiewe moment: "uitleg van die ontstaan van die gedig"}

In die lang aanhaling hierbo stel Breytenbach duidelik dat hy wil "uitlê hoe die gedig ontstaan". Ook uit die konteks wat ek kortliks hierbo geskets het, is dit duidelik dat Boek 'n nadenke oor kreatiwiteit is. Breytenbach voer aan dat die ontstaan van die gedig soos 'n ontbloting is wat in 'n flitsmoment of vlammehaal ontstaan (p. 5), waarna dit oorgeskryf en herskryf word - en uiteindelik gelees word.

Wanneer 'n mens sê dat die flitsmoment, die vlammehaal, 'n ontbloting is, mag dit lyk asof die oorspronklike impuls (daardie insig) iets is wat elders, buite ons bekende wêreld bestaan en wat aan die kunstenaar ontbloot word, sodat hy/sy dit net kan neerskryf vir ander om te lees. Dít ontken Breytenbach spesifiek. Hy verduidelik dat hierdie inspirasie nie van die engele af kom nie en dat hy nie in die Muse glo nie:

'Muse', inteendeel, was vir my nog steeds 'n bourgeoiskonsep. Ek sien hulle as swaar gegrimeerde (grimas - o, die wit modder!) want verwelkte 'jong' vroue, aanmekaar gewip op die tone om die afsaksels uit te stryk, en met die warmpatat la-di-da aksente van goedgeteelde Engelse ladies, geklee slegs in daardie lang deursigtige serpagtige goed (...) Ek sien die digters wat hulle frekwenteer (van hulle gebruik maak soos van handperde), met hulle opgesaal sit, as dandies uit die middestand uit op die jags, met 'n bietjie blinkwoord kwyl aan die snorre (...) (p. 49).

Die oorsprong van die kunswerk, daardie moment van insig, die vonk, kom alleen deur harde werk, maar nie as gevolg van harde werk nie. Ek kan dit nie soek nie, maar alleen voorbereid wees sodat dit my kan vind, verduidelik Breytenbach. Hy gebruik die taal van Boeddhisme om dit verder te verhelder, naamlik dat ek "die regte postuur moet inneem", dat die kunstenaar 'n geskikte onvangsapparaat of sisteem moet maak (p. 66). Hy verduidelik die voorbereiding, die inneem van die regte postuur, aan die hand van 'n persoonlike anekdote oor Opperman, wat vir hom gesê het toe hy as student enkele van sy verse aan Opperman gewys het, dat hy nadat hy nog 'n 1000 verse geskryf het, gereed sal wees om poësie te skryf. Dit is eers nadat 'n mens baie geoefen het en wanneer jy 'n vaardigheid met taal en tegniek en vorm bereik het, wat die onbewuste 'n kanaal deur daardie vaardigheid kan vind. 
Die moment van inspirasie word vergelyk met meditering - en hy skryf ook in die voorlaaste afdeling hoedat gedigte dikwels ná meditering na hom kom. Hierdie mediterende moment noem Breyten "inneraard 'n transenderende oomblik" (p. 39), omdat dit binne 'n mens gebeur.

Die kreatiewe moment wat in die kunswerk ontstaan, waaruit die kunswerk ontstaan, word nie sonder rede as 'n transenderende oomblik beskryf nie. In daardie moment kom iets tot stand wat buite dít val wat aan die kunstenaar bekend is. Die kunstenaar transendeer sigself - die eie kennis en emosies en kognitiewe patrone.

Daardie kreatiewe moment wat aanleiding gee tot die unieke gebeurtenis, tot die ontstaan van die enkele kunswerk, moet dus uit die bekende ontstaan.

Maar ons vertaal die onbekende en die nuut-ontdekte altyd met en in die taal van die bekende bekénde. Ons beskryf altyd iets met ' $n$ ander iets (p. 92).

Die kunstenaar het sekere kennis, ervarings, idees, gelowe, vrese, ideale. Kortom, om met Derek Attridge (2004:21) saam te praat, kan 'n mens sê die indviduele kunstenaar het 'n sekere idiokultuur. Elke individu het 'n spesifieke greep op die wêreld wat gemedieer word deur ' $n$ veranderende versameling van oorvleuelende, ineengestrengelde en dikwels teenstrydige kulturele sisteme wat oor 'n lang tyd geabsorbeer is deur ervaring. Die kulturele sisteme sluit die volgende in: 'n komplekse klomp gewoontes, kognitiewe modelle, voorstelle, geloofsoortuigings, verwagtings, vooroordele en voorkeure wat fisies, emosioneel en intellektueel werksaam is en wat 'n gevoel van relatiewe kontinuïteit, samehang en sin uit die veelvuldige gebeurtenisse van die lewe gee (Attridge, 2004:21). So 'n idiokultuur of "greep op die wêreld" mag redelik stabiel bly vir 'n tydperk, maar dit is eintlik onstabiel en voortdurend aan verandering onderworpe. $\mathrm{Al}$ is daar baie oorvleueling met ander mense (jou ouderdomsgroep, taalgroep, klas, ras, familie), is dit altyd 'n unieke konfigurasie.

Die kunstenaar het slegs hierdie bekende taal, die woordeskat, tot sy beskikking - slegs die gewoontes, kognitiewe modelle, voorstelle verwagtings, ensovoorts om mee te werk. Hierdie idiokultuur maak 'n mens in 'n sekere sin blind vir alles wat daarbuite val - 'n mens kan nie bewus wees van enigiets meer as wat binne jou idiokultuur val nie. Daarom skryf Breytenbach: 
My insig is ' $n$ belemmering. My visie maak dood. Sien is om blind te wees. My weergawe, wat 'n vertáling is, is 'n verdoeseling (p. 24).

Die kunstenaar neem iets waar - hetsy 'n eie emosie of iets in die wêreld om sigself en probeer uiting gee daaraan. So 'n waarneming of gewaarwording is egter nooit 'n ongeïnterpreteerde waarneming nie. Die kunstenaar se kennis, eie ervarings, agtergrond en opvoeding speel 'n rol in die waarneming. Die kunstenaar se greep op die wêreld, die idiokultuur, bepaal reeds die manier waarop die nuwe waarneming verstaan sal word. Jou manier van kyk maak jou dus blind vir ander maniere van sien. Joú insig belemmer ander moontlike insigte.

Wanneer die kunstenaar probeer om die werklikheid, daardie nuwe gewaarwordings, so getrou as moontlik soos dit aanvanklik ervaar is mee te deel, is die eerste probleem dat dit nooit presies gedoen kan word nie. Daardie spesifieke gewaarwording is juis ervaar deur 'n unieke individu met 'n unieke agtergrond en kennis, op 'n spesifike onherroepbare moment. Verder kan die ervaring nooit presies weergegee word nie, omdat die mededeling in 'n medium (bv. taal) gemaak word, wat nie van dieselfde aard is as die gewaarwording of waarneming nie. Ek moet 'n waarneming in taal omskakel - dit vertaal. Daar is egter net sekere konsepte en tegnieke (voorkennis) waarmee die unieke ervaring meegedeel kan word en daardeur word die moontlikheid om die ervaring weer te gee, beperk. Soos Breyten dit stel:

... dit is ook die gebrekkigheid van my vaardigheid, my woordeskat (en ook my ervaring word deur my woordeskat ingeperk - ek sién deur die woorde en dan vertel ek deur woorde, en woorde is staties in hierdie wêreld-in-vloei-enverkwetter); en dis veral die oogklappe van my konsepte en opinies (p. 23-24).

Daarom is sien, om blind te wees. My kennis van die konvensies en tradisie en konsepte maak my blind vir die volle werklikheid. En tog het die kunstenaar niks anders as hierdie bekende nie - en alles word vertaal na die bekende.

Wat gebeur tydens die skeppingsproses, is dat uit die hantering van hierdie bekende, 'n tot-nog-toe-onbekende spruit. Die (talige) skeppingsproses is dus die hantering van die bekende waaruit die tot-nog-toe onbekende spruit. Die kunstenaar worstel met die bekende - en uiteindelik spruit die onbekende uit daardie worsteling. 
Die kunstenaar slaag daarin om met die bekende patrone en vorms tot sy beskikking, iets tot stand te laat kom wat onbekend was (uit die tradisie - volgens Breytenbach 8 ).

Attridge noem hierdie iets wat tot stand kom, na aanleiding van Derrida en Levinas, die ander. Hy wil nie die term nuut daaraan koppel nie, omdat dit klink na iets beters wat die vorige, die oue vervang, terwyl dit nie waar is nie. Hierdie nuwe, die andere, is slegs kenbaar deur die oue (Attridge 2004:19):

Otherness is that which is, at a given moment, outside the horizon provided by the culture for thinking, understanding, imagining, feeling, perceiving.

Dit is hierdie alteriteit, hierdie andersheid, wat deur die skeppende flitsmoment, die vlammehaal, ontbloot word deur die kunstenaar. Belangrik ook hier is dat andersheid nie iets is wat in die gedig ontbloot word nie, dit ontstaan in die gedig:

Die gedig kan nie 'n beliggaming van die afwesigheid wees nie, die beeld is nie 'n belewenis van iets anders nie (dit ís iets anders), die relatiewe en die verwysende kan nie die Absolute beskryf nie (p. 26).

Dit is hierdie iets anders wat die crux van die kreatiewe moment is. Dit is die iets anders wat buite die kunstenaar se idiolek lê. Dit kom tot stand deur die bekende, maar dit is nie bloot 'n ander permutasie of kombinasie van die bekende nie. Soos Attridge (2004:25) dit stel:

The other brought into being in a creative event is thus at once implicit in the cultural field and wholly unpredictable from it.

Daar kan dus onderskei word tussen skepping en produksie. Skepping is die vaardige hantering van bekende materiaal, met ' $n$ oopheid vir suggesties van die ander, sodat alteriteit gekonfronteer word en die self uitbrei. Produksie, daarenteen, is die vaardige hantering van bekende materiaal volgens bekende patrone - dit bring geen alteriteit tot stand nie en lei nie tot transformasie van die kulturele veld (of die idiokultuur van die self) nie. Bekende elemente word herontplooi volgens aanvaarde norme.

8 Die kunstenaar vind dus dat hy altyd gebind word aan die tradisie:

As omgangsdier en imitasiedier - bewustelik, wat beteken dat ek verder as myself probeer loop - is dit nietemin onontkombaar dat ek altyd weer gebind word deur die tradisie, deur die ontdekking van ander, deur die weë waarlangs my medereisigers die Al probeer benader en vertaal (p. 24). 
... the point at which making becomes creating, or creating reverts to making, is never predictable, and can be assigned only after the fact (Attridge, 2004:25).

Die werklikheid is vir Breytenbach so omvattend groot dat ons dit nooit kan ken nie. Daardie onbekende van die werklikheid, dit wat nie omvat kan word nie, leer ons in skerfies ken, soos die ander, die onomvatbare in skerfies spieël onthul word. Die onthulling word natuurlik nie gemaak van 'n voorafbestaande onbekende anderkant die grense van my kennis nie, maar ontstaan in die kunswerk.

Ook Attridge sien dit so dat andersheid nie elders wag op onthulling nie, maar in die kunswerk tot stand kom. Die ander, hierdie andersheid is dus nie slegs "daar buite" nie, maar dit word geproduseer deur dieselfde handelinge waardeur die bekende gekonstitueer word! (Attridge, 2004:19).

Omdat die andersheid, daardie flitsmoment of vlammehaal, nie deur die muse ingegee word nie, nie by voorbaat iewers bestaan en wag op onthulling nie, kan die andersheid slegs ontstaan uit die bekende:

The creative mind can only work with the materials to which it has access, and it can have no certain knowledge beyond these; it therefore has to operate without being sure of where it is going, probing the limits of the culture's givens, taking advantage of their contradictions and tensions, seeking hints of the exclusion on which they depend for their existence, exploring the effects upon them of the encounters with the products and practices of other cultures (Attridge, 2004:20).

Die vasvang van die tot-nog-toe onbekende, of andersheid, die ander, probeer Breytenbach verduidelik aan die hand van 'n soort "skemateorie". Die skemateorie word afgelei uit Kant en impliseer dat menslike kennis deur sekere skemas bepaal word. Breytenbach se eerste punt oor die poësie is immers afgelei uit Gombrich se teorie van "maak en meet" soos Breytenbach dit vertaal (making and matching). Gombrich (1969:29, 173) se teorie van making and matching behels die volgende:

- Maak: Die digter/kunstenaar skep illusies. Aan die een kant "maak" die digter/die kunstenaar 'n illusie (Art as illusion). Hierdie illusie is die skema wat hy konstrueer om die wêreld uit te beeld. Breyten gebruik die woorde illusie, masker en skema (p. 19) om hierdie maakproses te beskryf.

- Meet: Sodra hy dit gemaak het, begin die kunstenar die skema of illusie te "meet" deur dit aan te pas by die "vereistes van 'n 
getroue weergawe". As maak die voorkeur geniet, lei dit tot illusies wat voorkeur geniet. As meet voorkeur geniet, word meer gekyk na die konvensies (al is dit sekerlik ook reeds gemaak, want 'n "getroue weergawe" van die werklikheid is bloot 'n weergawe wat volgens konvensies gemaak is).

Breytenbach sê die beslommernis is "dat die praktyk van die skyn 'n voorvereiste is tot die penetrasie en besitting van die syn" (p. 67-68). Dit is dus noodsaaklik dat 'n illusie geskep word - die maakgedeelte van die skema - voordat die syn, die self en selfbewussyn verstaan kan word. Later blyk dit dat dit deur hierdie illusies is wat ons die wêreld buite ons verstaan. Al wat ons het is die illusies - wat ook woorde is. Die woorde is immers 'n inbraak en uitreik. Hierdie idee van woorde wat "uitreik" en "inbreek", word in die volgende afdeling bespreek.

\section{Inbreek en uitreik}

Die eerste punt wat Breyten maak oor die poësie, is dat dit tegelyk ' $n$ inbreek en uitreik is. Die gedig is (ten minste) twee dinge: ' $n$ inbraak - 'n reik na binne, na die self, na die "onsigbare wêreld in ons" (p. 20), en 'n uitreik, 'n "gryp na dinge wat buite ons bestaan" (p. 18-19), die "sigbare wêreld om ons" (p. 20):

Aan die een kant is dit die "inbraak in daardie ruimte wat ons in ons omdra en waarvan ons deel is, dit wat op die punt van die tong lê, die groot Vermoede wat deur ontdekking werklikheid word, tegelyk ontdek en geskep" (p. 18). Met ander woorde, die gedig is 'n toegang tot die bewussyn, daardie onbekende en moeilik definieerbare aspek van die self - die breinaktiwiteit wat ons 'n bewussyn van onsself laat hê, en tot die onbewuste. Oor hierdie "onsigbare wêreld in ons" skryf Breyten die volgende: "dit het geen grense nie, en het dit ruimte? Of gee ons dit ruimte en aldus afbakening wanneer ons dit terugbring soos 'n vis uit die water?" (p. 20).

Aan die ander kant is die poësie 'n "gryp na dinge (...) wat buite ons bestaan". Hierdie dinge wat "buite ons bestaan" sluit nie slegs objekte in soos blomme of ander mense/geliefdes nie, maar ook emosies - my eie emosies sowel as ander se emosies - want soos Breyten dit stel: "my emosies maak van my die ánder" (p. 19). Die sigbare wêreld om ons beskryf hy onder meer as "die terrein waar ons onderlinge onsigbaarhede mekaar tref en sigbaar word, en alhoewel ek nie-konkrete dinge soos emosie en vermoëns hierby ingesluit het - ook jou eie kan en moet verplaas word, waargeneem 
word, speel hul buite jou af, is die katalisator van sigbaarheid" (p. 20).

Die eie bewussyn sowel as die sensories waarneembare wêreld is die ander, wat slegs tot stand kom in die gedig/in die kunswerk. Ek kan daardie andersheid nie ken, nie skeppend ontdek, sonder om die bekende te gebruik nie, maar ook nie sonder daardie skielike, vervreemdende moment van die vlammehaal nie.

\section{Skepping as vernuwing en verandering}

Die skepping is aan die een kant 'n vernuwing omdat dit vervreem. Dit is hier duidelik dat Breytenbach aansluit by die Russiese Formaliste se idees van vervreemding. Die digter moet vervreem maar soos Breytenbach dit beter stel:

Die digter bied 'n skeppie van dit wat verwag word aan, en probeer 'n skepping 'eie' daarmee saam insmokkel. Die digter kan 'n snoer van verwagtings skep byvoorbeeld - en dan met een klap 'n vars dermpie tussen die vlekkelose pêrels inryg. Of die Titanic (p. 35).

Skepping, die ervaring van die vlammehaal, is egter nie net vernuwend nie, dit bring ook verandering teweeg. Dit is nie bloot die ontstaan van die ander nie, maar hierdie ander het 'n effek op die bekende waaruit dit onthul is. Ons is aan die een kant besig om "die onbekende en nuut-ontdekte altyd in die taal van die bekende bekénde te vertaal", maar Breytenbach voer aan dat vertaling 'n effek het op die self, die ek, daardie "onomvatbare belewenispit". Die punt is dat die ek bestaan uit wat ek ontdek en waargeneem het, en dan vervolg hy: "Vervreemding geïntegreer word my uitbreiding, my voelhoring" (p. 92).

En die ruimte wat taal is, is gedeelde besit. Wat die maatskappy as gangbaar aanneem, die afgesproke konvensies, die algemeen aanvaarde ... speel ook ' $n$ rol, miskien selfs ' $n$ deurslaggewende rol. Ten slotte is daar veel wat ek goedsmoeds aanvaar, baie wat ek self nooit gesien of beleef het nie en wat 'n geïntegreerde en onbevraagtekende deel van my verwysingsveld word. Wat is dan subjektief en wat nie? Wat is bloot selfverwerende waarneming en wat realiteit? Asof die twee ooit skeibaar sou wees. Want ek kan nie objektiveer nie. Alle kontak impliseer keuse, aanvaarding, verwerking, verwerping ... Ek besluit subjektief om iets as objektiewe daarstelling te sien ... Ek deurleef die buiteruimte in terme en met die 'oë' van die binneruimte; ek deurleef die binneruimte deur die taal van wat buite my lê. In hierdie sin raak binne en buite 
mekaar aan, is daar interpenetrasie, onafskeidelikheid, en durf ek sê dat die een sonder die ander dimensieloos is. En daarom is dit moeilik om te besluit: wat bestáán en wat skép ek? Alles wat ek opdiep is waar. En wanneer ek dit uitdra en omdop, wanneer ek daarmee stoei en dit half-stukkend lêmaak op die wit mat van die papier, dan word dit ook vir ander waar (want dáár), of ten minste word dit 'n glas waardeur ander kan kyk. Hopelik ook sien. (En uiteindelik word ook dit kaduk en nie langer van toepassing nie.) (p. 92-93; my kursivering - WDB).

Die taal word as sintuig aangewend - deur die taal neem 'n mens waar, word die werklikheid en die self geskep (deur iets van buite 'n mens, naamlik taal). Die taal - ingespan op watter manier ookal word die waarheid, 'n glas waardeur 'n mens na die wêreld kyk.

Die idee dat ' $n$ blik op die self deur die aanwending van taal verkry word (deur taal as waarnemingsintuig), lei tot 'n bewustheid dat taal die werklikheid skep en ook die self skep. Dit is in hierdie verband wat identiteit so belangrik is in die werk van Breytenbach. Talle studies is al gewy aan die manier waarop 'n kamiljoen sy kleur verander, voortdurend nuwe identiteite tot stand bring met ander aliasse, Don Espejuelo, B.B. Lasarus en ander spieëls. Wat hier van belang is, is hoedat hierdie voortdurende verandering en verskuiwings in identiteit juis plaasvind as gevolg van die kreatiewe momente. In die gedigte waarin oor die "ek" geskryf word, kom telkens 'n ander tot stand; iets wat nie tevore daar was nie, kry 'n syn. En hierdie ander, hierdie vreemde, word geïntegreer deur die self en lei daarom tot 'n ander self, 'n ander identiteit. ("Vervreemding geïntegreer word my uitbreiding", staan daar immers op p. 92.)

Breytenbach beskryf die skryfproses soos volg: "skrywe is 'n vergestalting van lewe, 'n walgooi teen die stilte, teen die dood" (p. 144). Hierdie geskryf lei egter steeds meer tot 'n ontmoeting met die self.

Jou skrywe is soos 'n tou waaraan jy gelei word al hoe dieper die labirint in, die tou van altyd weer die onbekende bekende wat jy uit jou ryg; en met jou skrywe vleg jy, vleg jy - jy dink dat dit vlerke is maar al die tyd is dit 'n spieël (p. 144).

Skryf is dus 'n poging om wal te gooi teen die dood, en as sodanig is dit 'n poging om "vlerke te vleg" - vlerke waarmee jy, wanneer die liggaam ophou lewe, die siel kan vlug gee. Maar eindelik is al die geskryf eintlik ' $n$ manier om jouself te verken. Dit is 'n manier waarop die bewussyn verken word, en waardeur iets van die 
bewussyn waarneembaar gestalte kry. Jy skryf - en in die skryfsels wat uit jou voortkom, word die self gekonstateer - dit is die onbekende bekende wat jy uit jouself uitryg. Dit is dus 'n veranderde self wat voortdurend ontstaan deur die konfrontasie met die ander, wat tot stand kom in die kreatiewe proses; die onbekende wat uit die bekende tot stand kom word geïntegreer en verander die bekende self. "Jy maak die gedig en dit help jou maak" (p. 88).

Die gevolg is dat Breytenbach die self soos volg definieer:

Die self, die gewaande self, is ' $n$ kreatuur van die belewing van bewussyn en dié is ' $n$ neweproduk van die aaneengestippelde momente tyd, die vloei van die hede (p. 88).

Só beskou, is die self die hede. Die verlede is onherbeleefbaar verby. Daarmee ook al die "selwe" uit die verlede. Daarom sê Breyten "Die self is 'n lykswa" (p. 88). Die self is altyd wording.

Die gedig is dus 'n stukkie hede - bepaal deur wie ek is, hoe ek waarneem, hoe ek dink, hoe ek ervaar (as gevolg van al die kragte en invloede wat my gemaak het wat ek is). Maar dis ook 'n manier van vorentoe gryp, van vooruitkyk. Dit is toekomsgerig, want soos ek daardie gedig maak, vorm ek ook myself. Ek word weer op my beurt in die toekoms bepaal deur die manier waarop ek myself nou neerskryf. Die gedig help my maak. My subjektiwiteit verander deur die opeenvolging van kreatiewe momente waarin die self telkens met die ander gekonfronteer word. Uiteindelik word die self dus in 'n sekere sin die skepping van die ander! (Attridge, 2004:24).

Die skepping van die ander is dus sowel 'n vernuwing as 'n verandering van die oue. Aan die een kant kom die nuwe ander tot stand en aan die ander kant verander dit die vorige self. Wanneer ek die ander ervaar/ontmoet in die skielike moment waarin ek nog met die taal en woorde besig is en ' $n$ ander moontlikheid insien wat vroeër nie vir my bestaan het nie, kom die nuwe ander tot stand iets wat buite my idiokultuur, my horison gelê het. Aan die ander kant is ek nou ook nie meer dieselfde nie, ek is ver-ander, ek word self die ander en daarom anders.

'n Verdere aspek waarop Breytenbach klem plaas ten opsigte van die effek van die gedig op die self, hoedat die self tot stand kom in die gedig, is dat daardie self, soos dit tot stand kom, reeds "murasies" is, want die self woon immers nie meer daar nie - het klaar (in tyd) aanbeweeg! En selfs wanneer 'n mens daardie self in die gedig nie as murasies ervaar nie, maar soos Breytenbach dit stel, "as die mees modernistiese strukture van glas en staal, 
konstruksies wat oop en toe kan skuif, beton wat op yster skuur", bly hierdie "innerlike strukture" of "stellings" leeg, omdat hulle onbewoon is: "daar is die gewaarwording van - en rekening hou met - hierdie stellings, maar geen besetting nie. Die baas is uithuisig. Die ek slegs 'n verband" (p. 89).

Die self is altyd ' $n$ konstruksie en dan is die self klaar nie meer in daardie konstruksie nie - uiteraard nie, want dit neem dan hierdie konstruksie waar en staan, ten einde dit te kan doen, daarbuite. Die konstruksie is ook iets wat aan tyd gebonde is en dadelik verval tot murasie, tot wat agter lê, terwyl die self reeds weer in die nuwe hede inbeweeg het en die konstruksie daarom klaar agtergelaat het - dit nooit kan bewoon nie. Die self kan hoogstens "die verband hou" wat natuurlik weer interpreteer kan word as die "verbandhouer". Die eienaar wat afbetaal aan ' $n$ verband op die konstruksie, die huis; aan die ander kant slaan dit ook op die verband wat tussen al hierdie tydelike stukture van die self bestaan.

\section{Skepping as handeling en gebeurtenis}

Skepping is sowel 'n handeling as 'n gebeurtenis. Aan die een kant is die kunstenaar besig met die taal as waarnemingsintuig, as die bekende, as vorm. Aan die ander kant is dit egter ook gebeurtenis. Breytenbach verduidelik hierdie konsep aan die hand van Van Wyk Louw se opvatting van vorm en inhoud in sy bespreking van Celliers se poësie, naamlik dat die inhoud as't ware die vorm kies wanneer die vorm goed genoeg voorberei is.

Breytenbach sluit aan by die idee van Van Wyk Louw dat die "eintlike krag" van elke kunsenaar lê

in die dieper lae van sy wese as enige literêre strewe waarvan hy bewus is; voordat die laaste, bloot tegniese 'vorm' aan sy werk gegee word - feitlik 'n heeltemal bewuste taak van bou en rangskik - is die motief reeds in dieper sin onbewus 'gevorm' tot beeld en klank (...). Baie min of geen poësie word suiwer soos outomatiese skrif opgeteken; en die digter is nie net die spreekbuis van sy onbewuste ego nie (Louw aangehaal in Breytenbach, p. 64).

Volgens Breyten kan hierdie opvatting van Louw nog verder gevoer word. Aan die een kant het ons "skemas" - maniere of gewoontes, selfs 'n woordeskat (of taal) waarmee ons ingryp op die nie-verbale. Hierdie skemas is "aangeleerde rites, kortpaadjies" wat ook andersom werk. Dit is nie alleen kortpaadjies waarmee jy "dit wat in jou ontspring" kan oordra nie, dit is ook aanknopingspunte 
waarlangs die "ongerealiseerde lae en uitkorwende beeldlose handelinge van die syn" kontak met jóú kan maak - jy gee dus uitdrukking aan die bewussyn, maar die bewussyn kom onder andere tot jou deur die uitdrukkings, die skemas (p. 67).

Breytenbach sê vêrder "dat die praktyk van die skyn 'n voorvereiste is tot die penetrasie en besitting van die syn" (p. 67-68). Wat hy uiteindelik hiermee bedoel, so lyk dit my, is dat 'n mens se gereedskap geoefen moet wees: jy moet tallose verse maak, sodat jy die tegniek onder die knie kry, sodat wanneer die inspirasie die dag kom, jy kan skryf. Dit gaan nie help om te sit en wag nie. Die inspirasie kom ook uit die slyp van gereedskap - die bewussyn kom tot jou deur die uitdrukking en skemas. Maar dit beteken nog veel meer! Dit dui daarop dat die gebruik van die bekende, van taal en woorde en grammatika wat ons ken, 'n praktyk van die skyn is. Daarsonder kan ons egter nie iets van ons bestaan begryp nie.

Om die grens tussen die "jou" en die "reële", die "onbewuste" te laat verkrummel, neem die "ongedanste dans", die "immobiele sprong" (p. 124) wat nie deur "rasionaliteit of intensie veroorsaak kan word nie" (p. 124). Daarom is die gedig nie alleen handeling nie maar ook gebeurtenis.

\section{Samevatting}

“"n Gedig," skryf Breyten Breytenbach (p. 105), "bestaan grotendeels úit woorde." Dit is 'n tipiese Breytenbach-stelling. Dit is 'n voor die hand liggende stelling. Gedigte bestaan mos, soos ons almal weet, uit woorde. Maar deur die klem te plaas op "úit", ontstaan ook 'n tweede betekenismoontlikheid: dat die gedig, grotendeels, buite woorde bestaan.

Wat 'n doodgewone stelling kon wees, word deur hierdie beklemtoning iets heeltemal anders. Breytenbach gaan dikwels op hierdie manier te werk. Hy gebruik bekende uitdrukkings, liedjies of spreuke en breek hulle dan af en stel hulle in 'n ander konteks. Talle kreatiewe kopieskrywers wend ook hierdie tegniek met vrug aan wanneer advertensies gemaak word.

Die nuwe betekenis wat tot stand kom deur die afbreek van die bekende ou betekenis, is tot 'n groot mate wat gebeur wanneer enige kunswerk tot stand kom.

Derek Attridge wys daarop dat hierdie ander betekenis wat deur die kreatiewe moment tot stand kom, nie vooraf reeds iewers bestaan 
en wag op ontdekking nie. Hierdie betekenis kom tot stand die moment waarop die bekende vervorm word. Die kunstenaar het immers net die bekende om mee te werk. Die kunstenaar soek as't ware voel-voel deur al die bekende woorde, idees, metodes en gedagtes, totdat daar op 'n gegewe moment só 'n ingewing kom waardeur 'n ander, tot-dusver-onbekende, moontlikheid tot stand kom.

Hierdie kreatiewe moment waarop die tot-dusver-onbekende uit die bekende losgeworstel word, kan egter nie op 'n resepmatige wyse voortgebring word nie. Ek kan nie nou 'n ander betekenis laat ontstaan deur in elke moontlike sin die klem te verskuif nie. Dit is juis in die onvoorspelbaarheid daarvan wat die kreatiewe geleë is. Die digter weet nie eers self hoe hy by hierdie idees uitkom nie.

Die kunstenaar kan hoogstens die bekende hanteer met die hoop dat die onbekende uiteindelik sal ontstaan. Dit is soms asof hierdie onbekende, die nuwe, as't ware uit 'n ander wêreld inbreuk maak op die kunstenaar se wêreld - asof die ontstaan van die kunswerk mét hom gebeur eerder as wat hy dit láát gebeur.

Een voorbeeld van hierdie ervaring van 'n kunstenaar dat sy kunswerk eintlik ten spyte van homself ontstaan, eerder as deur homself, is te sien by die beeldhouer, Jonty Jack, in Etienne van Heerden se Die swye van Mario Salviati (2000). Hy kan nie glo dat die beeld "Visman Steier" sy eie handewerk is nie, maar ervaar dit as iets wat net skielik "vanself" ontstaan het: "... ek is maar 'n houtsnyer, 'n kerwer, 'n boemelaar en 'n sinikus. Ek het nie talente om só ' $n$ beeld te maak nie - daarvoor is ek te beperk, God hoor my".

Sy aanroep van God bevestig dat die kunswerk wat hy deur sy houtsnywery en -kerwery tot stand gebring het, van elders afkomstig is, vir hom ingegee is. Hierdie ervaring van 'n (goddelike of die muse se) ingryp op jou eie bekende wêreld en dat jy sodoende gekonfronteer word met iets wat nog nie tot dusver vir jou bestaan het nie, het 'n veranderende effek op die kunstenaar. Hierna kan hy nie meer dieselfde wees nie - soos wat Visman Steier ook Jonty Jack se lewe verander het.

Die veranderende ervaring is egter nie slegs die kunstenaar s'n nie. Dit geld ook vir die waarnemer van die kunswerk. Omdat die leser ook skrywer is ("Om te lees is om te skryf", skryf Breyten immers ook!), omdat die kunswerk telkens deur die waarnemer daarvan op 
'n manier herskep word, het ook die waarnemer hierdie ervaring van 'n ingryp van elders op sy lewe.

Die konfrontasie met die ander, onbekende, ver-ander my immers. Dit is om hierdie rede wat die ervaring van kunswerke altyd onvoorspelbaar is en waarom daar nie op eenvoudige wyse uitkomste beskryf kan word vir die bestudering van kunswerke nie. Daarom bestaan die gedig grotendeels úit woorde.

Dit is uiteindelik deur middel van woorde, deur middel van taal as voelinstrument, wat die bewussyn verken en ondersoek kan word. Waar die neurowetenskap fokus op ondersoeke van die fisiologiese ankerpunte van bewussyn, bied die ondersoek van taal 'n ander punt van waar die ondersoek geloods kan word. Waar taal lank reeds in die psigo-analise beskou word as die toegangsroete tot die onbewuste, dui hierdie opmerkings van Breytenbach aan dat dit ook vir die bewussyn geld.

Deur egter te fokus op taal in die kreatiewe moment, in die poësie, word moontlikhede van die bewussynswerking ondersoek. In die gedig wat ontstaan uit die bewussyn se aanwending van taal, kan iets van die bewussyn herken word, maar dit is altyd 'n verkenning wat lei tot 'n verandering. Die bewussyn kan dus nooit vasgepen word nie. Juis hierdie onvaspenbaarheid word bes moontlik die beste deur die onvaspenbare van poësie weergegee.

\section{Geraadpleegde bronne}

ATTRIDGE, DEREK. 2004. The singularity of literature. London: Routledge.

BODEN, MARGARET. A. 1998. Consciousness and human identity: an interdisciplinary perspective. (In Cornwell, John, ed. Consciousness and human identity. Oxford: Oxford University Press. p. 1-20.)

BREYTENBACH, BREYTEN. 1971. Om te vlieg. Kaapstad: Buren.

BREYTENBACH, BREYTEN. 1987. Boek (deel 1). Bramley: Taurus.

BREYTENBACH, BREYTEN. 1997. TV-onderhoud in: Serfontein, Hennie. The I of the beholder. Johannesburg: SABC.

COETZEE, J.M. 1992. Doubling the point: essays and interviews. (Ed. David Attwell.) Cambridge: Harvard University Press.

CRICK, F.H.C. 1994. The astonishing hypothesis: the scientific search for the soul. New York: Macmillan.

DENNETT, D. 1991. Consciousness explained. London: Penguin.

DERRIDA, J. \& DUFOURMANTELLE, A. 2000. Of hospitality. Stanford: Stanford University Press.

GOMBRICH, E.H. 1969. Art and illusion: a study in the psychology of representation. Princeton: Princeton University Press.

JAMES, WILLIAM. 1890. Principles of psychology. New York: Holt. 
LIPTON, PETER. 1998. Binding the mind. (In Cornwell, John, ed. Consciousness and human identity. Oxford: Oxford University Press. p. 212-224.)

PENROSE, ROGER. 1994. Shadows of the mind: a search for the missing science of consciousness. Oxford: Oxford University Press.

SEARLE, J. 1992. The rediscovery of mind. Cambridge: MIT.

VAN HEERDEN, ETIENNE. 2000. Die swye van Mario Salviati. Kaapstad: Tafelberg.

\section{Kernbegrippe:}

bewussyn

Boek: tronkliteratuur

Breyten Breytenbach

funksie van kuns; poësie

\section{Key concepts:}

Boek: prison literature

Breyten Breytenbach

consciousness

functions of art; poetry 
Breyten Breytenbach se "Boek": die taal (poësie) as voelinstrument ... 